\title{
Clinical Attestation and Redox Mechanism of Ascorbic Acid in the Treatment of Cancer
}

\author{
Sanjib Bhattacharya
}

\section{Sanjib Bhattacharya}

West Bengal Medical Services Corporation Ltd., GN 29, Sector V, Salt Lake, Kolkata, West Bengal, INDIA.

Correspondence

\section{Dr. Sanjib Bhattacharya}

West Bengal Medical Services

Corporation Ltd., GN 29, Sector V,

Salt Lake, Kolkata-700091, West Bengal, INDIA.

Phone no: + 919874331777

E-mail: sakkwai@yahoo.com

History

- Submission Date: 01-05-2021;

- Review completed: 29-05-2021

- Accepted Date: 17-06-2021.

DOI : 10.5530/fra.2021.1.1

Article Available online

http://www.antiox.org

\section{Copyright}

(C) 2021 Phcog.Net. This is an openaccess article distributed under the terms of the Creative Commons Attribution 4.0 International license.

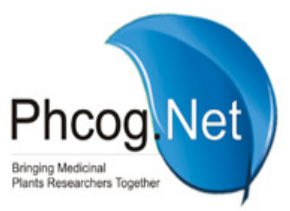

\begin{abstract}
Ascorbic acid (Vitamin C) is an essential micro-nutrient, an outstanding antioxidant and an essential co-factor in different mammalian enzymatic processes. There is considerable clinical attestation that, high dose of intravenous ascorbic acid can improve cancer patients with or without extant therapeutic involvements. Ascorbic acid in high intravenous doses serves as pro-oxidant and promotes the generation of hydrogen peroxide $\left(\mathrm{H}_{2} \mathrm{O}_{2}\right)$ and other reactive oxygen species (ROS) with oxidative stress-induced toxicity selectively to cancer cells. This effect also hampers the bioenergetics and angiogenesis of malignant cells, resulting in cancer cell death. Large doses of ascorbic acid are safe and well-tolerated. On account of its antioxidant effect, ascorbic acid supplementation may be applied as an adjuvant with regular cancer therapy to minimize complications. Nevertheless, there is a necessity for further mechanistic studies and randomized controlled clinical trials to evaluate the benefit of ascorbic acid in the treatment of cancer.
\end{abstract}

Key words: Ascorbic acid, Reactive oxygen species (ROS), Intravenous, Angiogenesis, Clinical.

\section{INTRODUCTION}

L-ascorbic acid (and its salts - ascorbate), commonly known as vitamin $C$, is a water-soluble vitamin micronutrient. Unlike most mammals and other animals, humans cannot synthesize this vitamin hence, should acquire it from the food. It is a natural product (phytochemical) found in higher plants - several fruits and vegetables and can also be synthesized. It was used for prevention and treatment of scurvy. Ascorbic acid (ascorbate) is an essential co-factor in several enzymatic biochemical reactions viz. biosynthesis of collagen, carnitine, and neuropeptides (including certain neurotransmitters) and in regulation of gene expression and immune system functions. It is also an excellent natural antioxidant. ${ }^{1}$

The anticancer effect of ascorbic acid has been appearing from more than the last six decades. In 1950s, there was a hypothesis that ascorbic acid exercises anticancer activity by promoting collagen synthesis. ${ }^{2,3}$ In 1972, the next hypothesis suggested that, the anticancer activity of ascorbic acid was owing to inhibition of hyaluronidase. ${ }^{4}$ The cytotoxic property of ascorbic acid was first reported in 1969, when sodium ascorbate was demonstrated to effect death of Ehrlich ascites carcinoma cells in vitro. ${ }^{5}$ The applications of intravenous ascorbic acid in cancer treatment had been investigated since the 1970s. ${ }^{6,7}$ Since then, ascorbic acid was receiving attention in management of human cancers. Numerous experimental pre-clinical and clinical studies put forward the favorable effects of ascorbic acid in prevention and treatment of different human cancers exhibiting oxidation-reduction (redox) mechanisms. The present review collates the noteworthy clinical attestations of cancer treatment with ascorbic acid and endeavors to critically explicate the underlying redox mechanisms.

\section{PHYSIOLOGICAL REDOX ROLES}

The prescribed daily dietary requirement of vitamin $\mathrm{C}$ is $75-90 \mathrm{mg}$. Ascorbic acid is a potent antioxidant or reducing agent, i.e., it donates electrons to recipient molecules - as per electronic redox concept. Due to this redox effect, there are two chief physiological roles of ascorbic acid: as an antioxidant and as an enzyme co-factor. ${ }^{1,8}$

Ascorbic acid is the non-enzymatic antioxidant systematically prevalent in blood and tissues. The normal blood plasma concentration of ascorbic acid is $50-100 \mu \mathrm{M}$ in healthy adults. Owing to antioxidant property, it is able to rapidly undergo gradual loss of one or two electrons i.e., successive oxidations, producing the relatively stable ascorbyl/ascorbate free radical (semidehydroascorbic acid) or unstable dehydroascorbic acid (DHA), respectively (Figure 1). Ascorbate radical can be reduced to ascorbic acid or may further be oxidized to DHA. In cells, DHA is readily reduced by glutathione 

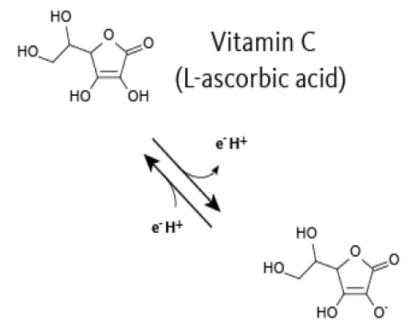

semidehydroascorbic acid

(ascorbate free radical)

Figure 1: Oxidation of ascorbic acid.

Table 1: The major enzymes requiring ascorbic acid as co-factor in mammals.

\begin{tabular}{|c|c|c|c|}
\hline $\begin{array}{l}\text { Sl. } \\
\text { No. }\end{array}$ & Enzyme types & Enzymes & Functions \\
\hline 1 & Monooxygenase & Dopamine $\beta$-monooxygenase & $\begin{array}{l}\text { Noradrenaline } \\
\text { biosynthesis }\end{array}$ \\
\hline 2 & & $\begin{array}{l}\text { Peptidyl-glycine } \alpha \text { amidating } \\
\text { monooxygenase }\end{array}$ & $\begin{array}{c}\text { Amidation of } \\
\text { peptide hormones }\end{array}$ \\
\hline 3 & Dioxygenase & $\begin{array}{l}3 \text { Prolyl 3-hydroxylase } \\
\text { isoenzymes }\end{array}$ & $\begin{array}{c}\text { Collagen } \\
\text { biosynthesis }\end{array}$ \\
\hline 4 & & $\begin{array}{l}3 \text { Lysyl hydroxylase } \\
\text { isoenzymes }\end{array}$ & \\
\hline 5 & & $\begin{array}{l}4 \text { Hypoxia-inducible factor } \\
\text { (HIF) isoenzymes }\end{array}$ & HIF hydroxylation \\
\hline 6 & & $\gamma$-Butyrobetaine hyroxylase & $\begin{array}{c}\text { Carnitine } \\
\text { biosynthesis }\end{array}$ \\
\hline 7 & & $\begin{array}{l}\text { 4-Hydroxyphenylpyruvate } \\
\text { dioxygenase }\end{array}$ & $\begin{array}{l}\text { Tyrosine } \\
\text { metabolism }\end{array}$ \\
\hline 8 & & $\begin{array}{c}\text { 10-11-translocation family of } \\
\text { dioxygenases }\end{array}$ & $\begin{array}{l}\text { Demethylation of } \\
\text { DNA }\end{array}$ \\
\hline
\end{tabular}

or thioredoxin to ascorbic acid. In this manner, ascorbic acid guards vital cellular bio-macromolecules like proteins, lipids and nucleic acids (DNA and RNA), from oxidative decomposition by free radicals/reactive oxygen species (ROS) that are produced on normal metabolic conditions and overproduced in disease conditions and invoked by toxins, xenobiotics (like drugs) and environmental contaminants. Ascorbic acid also takes part in redox salvage of other putative antioxidants, like regeneration of tocopherol (Vitamin E) from its oxidized state. ${ }^{9}$

The function of ascorbic acid as co-factor is also associated with its redox role. Ascorbate can chelate and reduce transition metal ions especially $\mathrm{Fe}^{3+}$ and $\mathrm{Cu}^{2+}$. Owing to this capability, ascorbate serves as an essential co-factor for several iron and copper-bearing enzymes. Ascorbate acts as co-factor for about 150 (one hundred fifty) human enzymes. By keeping enzyme-bound metals in their reduced state, ascorbic acid helps mixed-function oxidases for the synthesis of several prime biomolecules. ${ }^{1}$ These pertinent enzymes are either monooxygenases or dioxygenases (Table 1). Symptoms of Vitamin C deficiency, like slow wound healing and lethargy, cause from the disablement of these ascorbic acid-dependent enzymatic reactions resulting in the inadequate synthesis of catecholamines, carnitine, collagen etc. Furthermore, different dioxygenases are associated in the regulation of gene expression and the preservation of genome require ascorbic acid as a co-factor. For instance, ascorbate is entailed in the regulation of stability of hypoxia inducible factors (HIF) which mediate angiogenesis. ${ }^{10}$

\section{CLINICAL ATTESTATIONS IN CANCER TREATMENT}

Experiments performed in the 1970s revealed that, high doses (quite higher than normal dietary requirement) of intravenous ascorbic acid ( $10 \mathrm{~g} /$ day infused intravenously for 10 days) were helpful in extending the life span and improving the quality of life of terminal cancer patients. ${ }^{6,7}$ Concomitant clinical studies with same high dose (10 g/day) ascorbic acid given orally to advanced stage cancer victims however, demonstrated no significant increase in survival time. ${ }^{11,12}$ Therefore, is evident that, the intravenous route of ascorbic acid administration is crucial to attain this beneficial action. Compared to ascorbic acid administered orally, intravenous ascorbic acid can produce 30-70 times more plasma ascorbic acid concentrations. ${ }^{13,14}$ Outcome from recently conducted controlled clinical trials demonstrated that, intravenous ascorbic acid was safe and well tolerated by the cancer patients. There is no testimonial that, high dose of ascorbic acid (up to $10 \mathrm{~g}$ /day) impose any adverse or toxic reactions. ${ }^{15,16}$ Notwithstanding, while generally regarded as a nutraceutical or dietary supplement, neither the U.S. Food \& Drug Administration (US-FDA) nor European Medicines Agency has approved the usage of intravenous high dose ascorbic acid in the treatment of cancer. ${ }^{17}$

Further succeeding clinical investigations demonstrated that, combination of high dose ascorbic acid with conventional anticancer therapies retards cancer growth in human models of pancreatic, ${ }^{18,19}$ hepatic, ${ }^{20}$ breast, ${ }^{21}$ metastatic pancreatic cancer, ${ }^{22}$ sarcoma and malignant mesothelioma. ${ }^{23}$ The momentous prototypical clinical trials using intravenous ascorbic acid in treatment of cancer or obviation of anticancer treatment-invoked complications are summarized at Table 2. There is no proof that cancer advancement occurs with intravenous ascorbic acid supplementation. The recent study of 2018 is the evidence of randomized controlled phase II trial which seems to be the most motivating beneficial effect i.e., remission found in elderly acute myeloid leukemia patients in combination with chemotherapy (decitabine etc.), exhibiting a synergistic outcome. ${ }^{24}$ Few clinical studies using oral ascorbic acid administration till date yielded no response as stated in the foregoing paragraph, regardless of interventions.

Clinical trials of complementary high dose intravenous ascorbic acid infusion in cancer patients have improved the quality of life (QOL), as well as developments in physical and mental states and melioration of conventional cancer therapy-induced adverse events namely nausea, vomiting, fatigue, pain; hair, weight and appetite loss etc. ${ }^{10,21,22,25}$ Moreover, ascorbic acid has also reported to abrogate the harmful effects of radiation therapy ${ }^{26}$ and chemotherapeutic agents like bleomycin,${ }^{17} \operatorname{tamoxifen}^{27}$ etc when given by other routes (like oral) in low/pharmacological doses, causing decreased morbidity. ${ }^{28}$

Literature haunt unveils that, current attestations of the efficacy of intravenous ascorbic acid in cancer patients is restricted to observational studies, uncontrolled interventions, phase I/II studies and case reports. Interventions and patient population are divergent. The clinical efficacy should be determined exhaustively in specific cancer types or populations. Hence, there is a necessity for large, longer-duration, randomized controlled phase II clinical trials with proper controls that assess the efficacy of intravenous ascorbic acid in progression of specific cancers and survival thereof. ${ }^{16}$

\section{REDOX MECHANISM OF ANTICANCER EFFECT}

The mechanism of anticancer effect of intravenous ascorbic acid is still under critical exploration. Even though physiologically ascorbic acid serves as antioxidant, its therapeutic effectiveness at pharmacological or 
Table 2: Summary of important clinical studies on intravenous ascorbic acid in the treatment of cancer.

\begin{tabular}{|c|c|c|c|c|c|c|c|c|}
\hline SI. No. & $\begin{array}{l}\text { Year } \\
\text { reported }\end{array}$ & Study type & Dose (g) & Regimen & $\begin{array}{l}\text { Population } \\
\text { type, number of } \\
\text { patients }\end{array}$ & $\begin{array}{l}\text { Concomitant } \\
\text { chemotherapy/ } \\
\text { radiation/ } \\
\text { surgery }\end{array}$ & Efficacy & Reference no. \\
\hline 1 & 1976 & Observational & 10 & $\begin{array}{l}\text { Daily for } 10 \\
\text { days }\end{array}$ & $\begin{array}{c}\text { Advanced cancer, } \\
100\end{array}$ & None & $\begin{array}{l}\text { OS prolonged, } 4 \\
\text { times }\end{array}$ & 6 \\
\hline 2 & 1978 & Observational & 10 & $\begin{array}{l}\text { Daily for } 10 \\
\text { days }\end{array}$ & $\begin{array}{c}\text { Advanced cancer, } \\
100\end{array}$ & None & $\begin{array}{l}\text { OS prolonged } 4.6 \\
\text { times }\end{array}$ & 7 \\
\hline 3 & 1982 & Observational & $10-20$ & Daily & $\begin{array}{c}\text { Advanced cancer, } \\
111\end{array}$ & None & $\begin{array}{c}\text { OS prolonged } 5.7 \\
\text { times, improved } \\
\text { QOL }\end{array}$ & 29 \\
\hline 4 & 1991 & Observational & $10-45$ & Several & $\begin{array}{c}\text { Advanced cancer, } \\
294\end{array}$ & Yes & $\begin{array}{l}\text { OS prolonged } 1.9 \\
\text { times }\end{array}$ & 30 \\
\hline 5 & 2005 & Phase I & $10-50$ & $\begin{array}{l}\text { Daily for } 8 \\
\text { weeks }\end{array}$ & $\begin{array}{c}\text { Advanced cancer, } \\
294\end{array}$ & None & Stable & 31 \\
\hline 6 & 2007 & Observational & 10 & $\begin{array}{l}\text { Twice with } 3 \\
\text { days interval }\end{array}$ & Stage IV cancer, 39 & None & Improved QOL & 28 \\
\hline 7 & 2008 & Phase I & $0.4-1.5 / \mathrm{kg}$ & $\begin{array}{l}\text { Thrice in a } \\
\text { week for } 2 \\
\text { weeks }\end{array}$ & $\begin{array}{l}\text { Solid and leukemic, } \\
\qquad 24\end{array}$ & None & $\begin{array}{c}\text { Stable, Improved } \\
\text { QOL }\end{array}$ & 32 \\
\hline 8 & 2011 & Observational & 7.5 & $\begin{array}{l}\text { Weekly for } 4 \\
\text { weeks }\end{array}$ & $\begin{array}{l}\text { Stage II breast } \\
\text { cancer, } 53\end{array}$ & Yes & $\begin{array}{l}\text { Improved QOL } 2 \\
\text { times }\end{array}$ & 21 \\
\hline 9 & 2012 & Observational & 50 & $\begin{array}{c}\text { Thrice in a } \\
\text { week, median } \\
9 \text { treatments }\end{array}$ & $\begin{array}{l}\text { Prostate and other } \\
\text { cancers, } 45\end{array}$ & None & $\begin{array}{c}\text { Decreased PSA and } \\
\text { CRP }\end{array}$ & 33 \\
\hline 10 & & Observational & 50 & $\begin{array}{l}\text { Twice in a } \\
\text { week for } 4 \\
\text { weeks }\end{array}$ & Advanced cancer, 60 & None & Improved QOL & 34 \\
\hline 11 & & Phase I & $50-100$ & $\begin{array}{l}\text { Thrice in a } \\
\text { week for } 8 \\
\text { weeks }\end{array}$ & $\begin{array}{l}\text { Stage IV pancreatic } \\
\text { cancer, } 9\end{array}$ & $\begin{array}{l}\text { Gemcitabine and } \\
\text { Erlotinib }\end{array}$ & $\begin{array}{l}\text { Tumor mass } \\
\text { reduced, OS } \\
\text { prolonged }\end{array}$ & 22 \\
\hline 12 & 2013 & Phase I/IIA & $50-125$ & $\begin{array}{l}\text { Twice in a } \\
\text { week for } 4 \\
\text { weeks }\end{array}$ & $\begin{array}{l}\text { Stage IV pancreatic } \\
\text { cancer, } 9\end{array}$ & Gemcitabine & $\begin{array}{l}\text { Improved QOL, OS } \\
\text { prolonged }\end{array}$ & 35 \\
\hline 13 & & Phase I & $50-110 / \mathrm{m}^{2}$ & $\begin{array}{c}\text { Four times in } \\
\text { a week for } 4 \\
\text { weeks }\end{array}$ & Solid tumors, 17 & Ecosapentanoic acid & Stable & 20 \\
\hline 14 & 2014 & Phase I/IIA & $75-100$ & $\begin{array}{c}\text { Twice/thrice } \\
\text { in a week for } \\
1 \text { year }\end{array}$ & $\begin{array}{l}\text { Stage III-IV ovarian } \\
\text { cancer, } 27\end{array}$ & $\begin{array}{l}\text { Paclitaxel and } \\
\text { carboplatin }\end{array}$ & $\begin{array}{l}\text { Prolongation of } \\
\text { relapse }\end{array}$ & 36 \\
\hline 15 & 2015 & $\begin{array}{l}\text { Phase IIA: } \\
\text { uncontrolled }\end{array}$ & $\begin{array}{c}86-124(1.5 \\
\mathrm{g} / \mathrm{kg})\end{array}$ & $\begin{array}{l}\text { Thrice in a } \\
\text { week for } 11- \\
580 \text { days }\end{array}$ & Advanced cancer, 14 & Yes & $\begin{array}{l}\text { Stable, partly long } \\
\text { lasting disease }\end{array}$ & 37 \\
\hline 16 & 2017 & $\begin{array}{c}\text { Phase II: } \\
\text { uncontrolled }\end{array}$ & $5-60$ & $\begin{array}{l}\text { Weekly for } 12 \\
\text { weeks }\end{array}$ & $\begin{array}{c}\text { Metastatic } \\
\text { castration-resistant } \\
\text { prostate cancer, } 23\end{array}$ & None & $\begin{array}{l}\text { Marginal } \\
\text { improvement of } \\
\text { QOL }\end{array}$ & 38 \\
\hline 17 & 2018 & $\begin{array}{l}\text { Phase IIB: } \\
\text { randomized } \\
\text { controlled }\end{array}$ & $\begin{array}{c}50-80 \mathrm{mg} / \\
\mathrm{kg}\end{array}$ & $\begin{array}{l}10 \text { Days per } \\
\text { month, for } 10 \\
\text { Months }\end{array}$ & $\begin{array}{c}\text { Acute } \\
\text { myeloid leukemia, } \\
39\end{array}$ & $\begin{array}{l}\text { Decitabine, } \\
\text { cytarabine and } \\
\text { aclarubicin }\end{array}$ & $\begin{array}{l}\text { OS prolonged } 1.6 \\
\text { times, remission rate } \\
\text { higher }\end{array}$ & 24 \\
\hline
\end{tabular}

Notes: OS: Overall survival; QOL: Quality of life; PSA: Prostate specific antigen; CRP: C-reactive protein. 


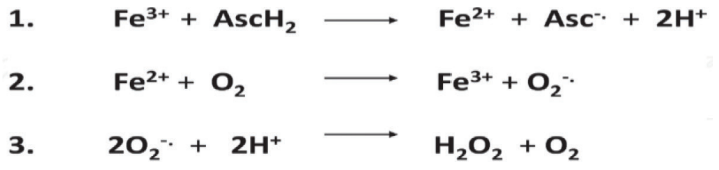

Figure 2: Fenton reaction of ascorbic acid.

higher doses in most cancer cases seems to be connected to pro-oxidant effects eventually causing cancer cell death. ${ }^{14,39}$

The recent mechanistic studies are based on reactive oxygen species (ROS) induced cellular events, because the generation of hydrogen peroxide $\left(\mathrm{H}_{2} \mathrm{O}_{2}\right)$ is cardinal event in ascorbate-induced anticancer effect; and $\mathrm{H}_{2} \mathrm{O}_{2}$ is a ROS that can generate ROS down-stream through transmetal catalyzed Fenton reaction. ${ }^{14,39,40}$ This reaction is the oxidation of organic substrates such as ascorbic acid by iron (III) to produce $\mathrm{H}_{2} \mathrm{O}_{2}$ (Figure 2).

1. Ascorbic acid $\left(\mathrm{AscH}_{2}\right)$ reduces ferric ions $\left(\mathrm{Fe}^{3+}\right)$ to ferrous ions $\left(\mathrm{Fe}^{2+}\right)$.

2. Ferrous ion reacts with oxygen to produce superoxide radical.

3. Dismutation of superoxide generates hydrogen peroxide.

Ascorbic acid selectively ruins cancer cells through the intracellular production of toxic $\mathrm{H}_{2} \mathrm{O}_{2}$ generated upon its oxidation through aforesaid scheme. High doses of ascorbic acid after intravenous administration serves as a peroxide delivery system (pro-drug) for the generation of stable ascorbate radical and $\mathrm{H}_{2} \mathrm{O}_{2}$, with concurrent selective oxidative damage of cancer cells. ${ }^{40,41}$ Cancer cells, as compared to normal ones, show impaired endogenous enzymatic antioxidant mechanism consisting of superoxide dismutase, catalase, glutathione $S$-transferase, glutathione peroxidase etc. The reduced activity of antioxidant enzymes hinders further degradation of $\mathrm{H}_{2} \mathrm{O}_{2}$ thus causing intracellular accumulation of $\mathrm{H}_{2} \mathrm{O}_{2}$ (ROS) which in turn, generate more ROS downstream as per the chain reactions leading to intracellular redox imbalance and oxidative impact resulting in oxidative damage to cellular vital macromolecules and organelle. Normal cells having competent endogenous enzymatic defense system, detoxifies $\mathrm{H}_{2} \mathrm{O}_{2}$ regularly - therefore, no or less cellular accumulation and resultant cytotoxicity. ${ }^{40-42}$

In human body, ascorbic acid is oxidized to dehydroascorbic acid (DHA) which is then reduced further to ascorbic acid within the cells (see above). The reduction of DHA to ascorbic acid scavenges reduced glutathione (GSH). It also acts as reducing agent (antioxidant) when it detoxifies hydrogen peroxide (ROS) by means of the enzyme glutathione peroxidise. GSH thus functions as the cellular non-enzymatic antioxidant defence as it abrogates oxidative stress by reducing ROS. Hence, depletion of GSH content invokes weakening of non-enzymatic redox mechanism and elicits oxidative impact leading to death of cancer cells. $^{43,44}$

Recent studies suggest a salient relationship between ascorbic acid and GSH entailing glucose metabolism including glycolysis, tricarboxylic acid cycle (TCA) or citric acid cycle and pentose phosphate pathway. Ascorbate-induced oxidative stress with depletion of GSH, results in inhibition of a glycolytic enzyme viz. glyceraldehyde-3-phosphatedehydrogenase (GAPDH). ${ }^{44,45}$ Therefore, the upstream GAPDH metabolites i.e., metabolites associated with upstream glycolysis, partial TCA cycle (e.g., citrate and cis-aconitate) and pentose phosphate pathway accumulate whereas downstream metabolites of GAPDH are degraded except citrate and cis-aconitate. High dose of ascorbic acid reduces the synthesis of ATP, as high dose ascorbic acid interferes with glycolysis and TCA cycle energy metabolism, consequently restricting ATP production. Ascorbic acid-mediated oxidative insult, in turn, induces the depletion of $\mathrm{NADH}$, which also obstructs glycolytic pathway. The decreased ATP level leads to intracellular energy crisis which results in cancer cell death. ${ }^{46,47}$
In accordance with this mechanism, ascorbic acid acting as a pro-oxidant, increases the intracellular reactive oxygen species (ROS), which leads to genotoxicity i.e., DNA damage, with consequent activation of poly ADPribose polymerase (PARP), an enzyme required for DNA repair. PARP activation in turn quenches $\mathrm{NAD}^{+}$with $\mathrm{NAD}^{+}$depletion and resultant ADP degradation, leading to energetic dearth and death of malignant cells. $^{47,48}$

Due to mitochondrial dysfunction and lack of adequate oxygen supply i.e., hypoxia in the tumor microenvironment owing to deficient blood circulation, cancer cells live mainly on glycolysis for ATP production, hence their ATP synthesis is not efficient as compared with normal cells which generally utilize oxidative phosphorylation. ${ }^{49,50}$ Therefore, the cancer cells become more vulnerable to ascorbate-induced oxidative stress-mediated energetic paucity than normal cells. ${ }^{51}$ Nevertheless, the selective anticancer action of ascorbic acid against cancer cells and its mechanisms require further investigations.

Ascorbic acid and DHA-induced perturbations in the cellular redox system decreases the available nitric oxide (NO) in endothelial tissues. NO is regarded as a main impetus for new blood vessel formation i.e., angiogenesis. Angiogenesis is the pertinent event for most of the solid tumors to get rid of hypoxia. NO pathways are the key elicitors of tumor angiogenesis. High concentrations of ascorbates impedes the generation of NO therefore; high concentrations of ascorbic acid have been demonstrated to prevent angiogenesis. Intracellular downregulation of HIF (which is generally upregulated in solid tumors) by ascorbic acid can also induce angiostasis. Ascorbic acid is thus found to limit tumor angiogenesis, resulting in prevention of carcinogenesis in experimental animals. . $^{17,52,53}$

The role of reactive oxygen species (ROS) in pathogenesis of cancer has duly been established. ${ }^{54}$ Physiological levels of ascorbic acid effectively detoxify ROS that are produced during normal metabolism and overproduced under different types of stress and disease conditions owing to antioxidant effect..$^{55}$ Therefore, ascorbic acid protects tissue damage and death induced by pro-oxidant stressors viz. xenobiotics and pollutants. ${ }^{9}$ It is apparent that, alleviation in toxicity of extant chemotherapy and/ or radiotherapy on normal tissue upon complementary co-treatment with ascorbic acid is associated with abrogation of concomitant oxidative injury to non-target normal cells thereby improving the life quality of patients receiving chemo/radiotherapy, demonstrating its benefit to be applied as adjuvant or palliative treatment. ${ }^{56,57}$

\section{CONCLUSION}

Ascorbic acid, a phytochemical (natural product), is an essential vitamin micro-nutrient, a potent antioxidant and essential co-factor in several major mammalian enzymes. There is significant clinical proof that, high dose intravenous ascorbic acid can improve the condition of cancer patients with or without typical therapeutic interventions. The effect is observed particularly with intravenous than oral application. High dose intravenous ascorbic acid is found safe and well endured in cancer patients. Nonetheless, the clinical efficacy requires to be assessed congruently in specific types of cancer. Hence, there is need for definitively designed randomized controlled clinical trials to evaluate the efficacy of intravenous ascorbic acid in treatment of neoplastic diseases. Ascorbic acid supplementation may also be employed as adjuvant with conventional cancer therapies to circumvent corresponding complications. The clinical data attest to conclude that, ascorbic acid possesses the prospect to be an effective, innocuous, easily available cancer therapy in due course. Mechanistically, ascorbic acid at large intravenous doses, acts as a pro-oxidant and promotes intracellular hydrogen peroxide $\left(\mathrm{H}_{2} \mathrm{O}_{2}\right)$ and other ROS generation leading oxidative stress-mediated selective aftermath to malignant cells. This effect also interferes with bioenergetics 
and angiogenesis of cancer cells, causing cancer cell death. The molecular mechanisms of its selective actions against cancer cells warrant advanced studies. Further clinical as well as mechanistic studies are the need of the hour to reap the absolute benefits of this vitamin in cancer therapy.

\section{CONFLICT OF INTEREST}

The author declares no conflict of interest.

\section{ABBREVIATIONS}

ROS: Reactive oxygen species; ATP: Adenosine triphosphate; ADP: Adenosine diphosphate; DHA: Dehydroascorbic acid; NADH: Nicotinamide adenine dinucleotide (reduced); PARP: Poly ADP-ribose polymerase; DNA: Deoxyribonucleic acid; RNA: Ribonucleic acid; QOL: Quality of life; $\mathbf{H}_{2} \mathrm{O}_{2}$ : Hydrogen peroxide; GAPDH: Glyceraldehyde-3phosphate-dehydrogenase; GSH: Reduced glutathione.

\section{REFERENCES}

1. Levine M, Padayatty SJ. Vitamin C. In: Ross AC Caballero B, Cousins RJ, Tucker KL, Ziegler TR, editors Modern nutrition in health and disease. 11th ed. Baltimore: Lippincott Williams \& Wilkins; 2014. p. 416-26.

2. McCormick WJ. Cancer: the preconditioning factor in pathogenesis; a new etiologic approach. Arch Pediatr. 1954;71(10):313-22. PMID 13208373.

3. McCormickWJ. Cancer: a collagen disease, secondary to a nutritional deficiency. Arch Pediatr. 1959;76(4):166-71. PMID 13638066

4. Cameron E, Rotman D. Ascorbic acid, cell proliferation, and cancer. Lancet 1972:1(7749):542. doi: 10.1016/s0140-6736(72)90215-2, PMID 4110043

5. Benade L, Howard T, Burk D. Synergistic killing of Ehrlich ascites carcinoma cells by ascorbate and 3-amino-1, 2. Oncol. 1969;23: 33-43:4-triazole.

6. Cameron E, Pauling L. Supplemental ascorbate in the supportive treatment of cancer: prolongation of survival times in terminal human cancer. Proc Natl Acad Sci U S A. 1976;73(10):3685-9. doi: 10.1073/pnas.73.10.3685, PMID 1068480

7. Cameron E, Pauling L. Supplemental ascorbate in the supportive treatment of cancer: re-evaluation of prolongation of survival times in terminal human cancer. Proc Natl Acad Sci U S A. 1978;75(9):4538-42. doi: 10.1073/pnas.75.9.4538, PMID 279931

8. Padayatty SJ, Levine M. Vitamin C: the known and the unknown and Goldilocks Oral Dis. 2016;22(6):463-93. doi: 10.1111/odi.12446, PMID 26808119

9. Li R. Vitamin C, a multi-tasking molecule, finds a molecular target in killing cancer cells. React Oxyg Species (Apex). 2016;1(2):141-56. doi: 10.20455/ ros.2016.829, PMID 29780883.

10. Bánhegyi G, Benedetti A, Margittai E, Marcolongo P, Fulceri R, Németh CE, Szarka A. Subcellular compartmentation of ascorbate and its variation in disease states. Biochim Biophys Acta. 2014;1843(9):1909-16. doi: 10.1016/j. bbamcr.2014.05.016, PMID 24907663

11. Creagan ET, Moertel CG, O'Fallon JR, Schutt AJ, O'Connell MJ, Rubin J, Frytak S Failure of high-dose vitamin $\mathrm{C}$ (ascorbic acid) therapy to benefit patients with advanced cancer. A controlled trial. N Engl J Med. 1979;301(13):687-90. doi 10.1056/NEJM197909273011303, PMID 384241

12. Moertel CG, Fleming TR, Creagan ET, Rubin J, O'Connell MJ, Ames MM. High-dose vitamin $C$ versus placebo in the treatment of patients with advanced cancer who have had no prior chemotherapy. A randomized double-blind comparison. N Engl J Med. 1985;312(3):137-41. doi: 10.1056/NEJM198501173120301, PMID 3880867.

13. Padayatty SJ, Sun H, Wang Y, Riordan HD, Hewitt SM, Katz A, Wesley RA, Levine M. Vitamin C pharmacokinetics: implications for oral and intravenous use. Ann Intern Med. 2004;140(7):533-7. doi: 10.7326/0003-4819-140-7200404060-00010, PMID 15068981.

14. Levine M, Padayatty SJ, Espey MG. Vitamin C: a concentration-function approach yields pharmacology and therapeutic discoveries. Adv Nutr. 2011:2(2):78-88. doi: 10.3945/an.110.000109, PMID 22332036.

15. Ohno S, Ohno Y, Suzuki N, Soma G, Inoue M. High-dose vitamin C (ascorbic acid) therapy in the treatment of patients with advanced cancer. Anticancer Res. 2009;29(3):809-15. PMID 19414313.

16. Nauman G, Gray JC, Parkinson R, Levine M, Paller CJ. Systematic review of intravenous ascorbate in cancer clinical trials. Antioxidants (Basel). 2018;7(7):E89. doi: 10.3390/antiox7070089, PMID 30002308.

17. Blaszczak W, Barczak W, Masternak J, Kopczynski P, Zhitkovich A, Rubis B. Vitamin $C$ as a modulator of the response to cancer therapy. Molecules. 2019;24(3):E453. doi: 10.3390/molecules24030453, PMID 30695991.

18. Du J, Martin SM, Levine M, Wagner BA, Buettner GR, Wang SH, Taghiyev AF Du C, Knudson CM, Cullen JJ. Mechanisms of ascorbate-induced cytotoxicity in pancreatic cancer. Clin Cancer Res. 2010;16(2):509-20. doi: 10.1158/10780432. CCR-09-1713, PMID 20068072.
19. Espey MG, Chen P, Chalmers B, Drisko J, Sun AY, Levine M, Chen Q. Pharmacologic ascorbate synergizes with gemcitabine in preclinical models of pancreatic cancer. Free Radic Biol Med. 2011;50(11):1610-9. doi: 10.1016/j. freeradbiomed.2011.03.007, PMID 21402145.

20. Stephenson CM, Levin RD, Spector T, Lis CG. Phase I clinical trial to evaluate the safety, tolerability and pharmacokinetics of high-dose intravenous ascorbic acid in patients with advanced cancer. Cancer Chemother Pharmacol. 2013;72(1):139-46. doi: 10.1007/s00280-013-2179-9, PMID 23670640.

21. Vollbracht $C$, Schneider B, Leendert V, Weiss G, Auerbach L, Beuth J. Intravenous vitamin $C$ administration improves quality of life in breast cancer patients during chemo-/radiotherapy and aftercare: results of a retrospective, multicentre, epidemiological cohort study in Germany In Vivo 2011:25(6):983-90. PMID 22021693

22. Monti DA, Mitchell E, Bazzan AJ, Littman S, Zabrecky G, Yeo CJ, Pillai MV Newberg $A B$, Deshmukh $S$, Levine $M$. Phase I evaluation of intravenous ascorbic acid in combination with gemcitabine and erlotinib in patients with metastatic pancreatic cancer. PLOS ONE. 2012;7(1):e29794. doi: 10.1371/ journal.pone.0029794, PMID 22272248.

23. Frei $B$, England $L, A$ mes $B N$. Ascorbate is an outstanding antioxidant in human blood plasma. Proc Natl Acad Sci U S A. 1989;86(16):6377-81. doi: 10.1073/ pnas.86.16.6377, PMID 2762330.

24. Zhao $\mathrm{H}$, Zhu $\mathrm{H}$, Huang J, Zhu Y, Hong M, Zhu H, Zhang J, Li S, Yang L, Lian Y, Wang $\mathrm{S}$, Mao J, Chen Y, Li J Oian S. The synergy of vitamin C with decitabine activates TET2 in leukemic cells and significantly improves overall survival in elderly patients with acute myeloid leukemia. Leuk Res. 2018:66:1-7. doi: 10.1016/j.leukres.2017.12.009, PMID 29331774.

25. Naidu KA. Vitamin C in human health and disease is still a mystery? An over view. Nutr J. 2003:2:7. doi: 10.1186/1475-2891-2-7. PMID 14498993.

26. Velauthapillai N, Barfett J, Jaffer H, Mikulis D, Murphy K. Antioxidants taken orally prior to diagnostic radiation exposure can prevent DNA injury. J Vasc Interv Radiol. 2017:28(3):406-11. doi: 10.1016/j.jvir.2016.10.022, PMID 28034704

27. Subramani $T$, Yeap SK, Ho WY, Ho CL, Omar AR, Aziz SA, Rahman NM, Alitheen NB. Vitamin C suppresses cell death in MCF-7 human breast cance cells induced by tamoxifen. J Cell Mol Med. 2014;18(2):305-13. doi: 10.1111/ jcmm.12188, PMID 24266867.

28. Yeom CH, Jung GC, Song KJ. Changes of terminal cancer patients' healthrelated quality of life after high dose vitamin $\mathrm{C}$ administration. J Korean Med Sci. 2007;22(1):7-11. doi: 10.3346/jkms.2007.22.1.7, PMID 17297243.

29. Murata A, Morishige $F$, Yamaguchi $H$. Prolongation of survival times of termina cancer patients by administration of large doses of ascorbate. Int J Vitam Nutr Res Suppl. 1982;23:103-13. PMID 6811475

30. Cameron E, Campbell A. Innovation vs. quality control: an 'unpublishable' clinica trial of supplemental ascorbate in incurable cancer. Med Hypo. 1991;36(3):185-9. doi: 10.1016/0306-9877(91)90127-k, PMID 1787807.

31. Riordan HD, Casciari JJ, González MJ, Riordan NH, Miranda-Massari JR Taylor P Jackson JA A pilot clinical study of continuous intravenous ascorbate in terminal cancer patients. PR Health Sci J. 2005;24(4):269-76. PMID 16570523

32. Hoffer LJ, Levine M, Assouline S, Melnychuk D, Padayatty SJ, Rosadiuk K Rousseau C, Robitaille L, Miller WH. Phase I clinical trial of i.v. ascorbic acid in advanced malignancy. Ann Oncol. 2008;19(11):1969-74. doi: 10.1093/annonc/ mdn377, PMID 18544557.

33. Mikirova N, Casciari J, Rogers A, Taylor P. Effect of high-dose intravenous vitamin C on inflammation in cancer patients. J Transl Med. 2012;10:189. doi: 10.1186/1479-5876-10-189, PMID 22963460

34. Takahashi $H$, Mizuno $H$, Yanagisawa A. High-dose intravenous vitamin C improves quality of life in cancer patients. Pers Med Universe. 2012;1(1):49-53. doi: 10.1016/j.pmu.2012.05.008.

35. Welsh JL, Wagner BA, van't Erve TJ, Zehr PS, Berg DJ, Halfdanarson TR, Yee NS Bodeker KL, Du J, Roberts LJ, Drisko J, Levine M, Buettner GR, Cullen JJ. Pharmacological ascorbate with gemcitabine for the control of metastatic and node-positive pancreatic cancer (PacMan): results from a phase I clinical trial. Cancer Chemother Pharmacol. 2013:71(3):765-75. doi: 10.1007/s00280-0132070-8, PMID 23381814

36. Ma Y, Chapman J, Levine M, Polireddy K, Drisko J, Chen Q. High-dose parenteral ascorbate enhanced chemosensitivity of ovarian cancer and reduced toxicity of chemotherapy. Sci Transl Med. 2014;6(222):222ra18. doi: 10.1126/ scitranslmed.3007154, PMID 24500406

37. Hoffer LJ, Robitaille L, Zakarian R, Melnychuk D, Kavan P, Agulnik J, Cohen V Small D, Miller WH Jr. High-dose intravenous vitamin C combined with cytotoxic chemotherapy in patients with advanced cancer: A phase I-II clinical trial. PLOS ONE. 2015:10(4):e0120228. doi: 10.1371/journal.pone.0120228, PMID 25848948.

38. Nielsen TK, Højgaard M, Andersen JT, Jørgensen NR, Zerahn B, Kristensen $B$ Henriksen T, Lykkesfeldt J, Mikines KJ, Poulsen HE. Weekly ascorbic acid infusion in castration-resistant prostate cancer patients: A single-arm phase I trial. Transl Androl Urol. 2017;6(3):517-28. doi: 10.21037/tau.2017.04.42, PMID 28725594.

39. Chen Q, Espey MG, Sun AY, Pooput C, Kirk KL, Krishna MC, Khosh DB, Drisko J Levine M. Pharmacologic doses of ascorbate act as a prooxidant and decrease growth of aggressive tumor xenografts in mice. Proc Natl Acad Sci U S A 
2008;105(32):11105-9. doi: 10.1073/pnas.0804226105, PMID 18678913.

40. Chen Q, Espey MG, Sun AY, Lee JH, Krishna MC, Shacter E, Choyke PL, Pooput C Kirk KL, Buettner GR, Levine M. Ascorbate in pharmacologic concentrations selectively generates ascorbate radical and hydrogen peroxide in extracellular fluid in vivo. Proc Natl Acad Sci U S A. 2007;104(21):8749-54. doi: 10.1073/ pnas.0702854104, PMID 17502596.

41. Chen Q, Espey MG, Krishna MC, Mitchell JB, Corpe CP, Buettner GR, Shacter E, Levine M. Pharmacologic ascorbic acid concentrations selectively kill cancer cells: action as a pro-drug to deliver hydrogen peroxide to tissues. Proc Nat Acad Sci U S A. 2005;102(38):13604-9. doi: 10.1073/pnas.0506390102, PMID 16157892

42. van der Reest JV, Gottlieb E. Anti-cancer effects of vitamin C revisited. Cell Res. 2016;26(3):269-70. doi: 10.1038/cr.2016.7, PMID 26768769.

43. Chakraborty M, Bala A, Bhattacharya S, Haldar PK. Hypoglycemic effect of ethy acetate fraction of methanol extract from Campylandra aurantiaca rhizome on high-fat diet and low-dose streptozotocin-induced diabetic rats. Phcog Mag. 2018;14(59):539-45. doi: 10.4103/pm.pm_194_17.

44. Yun J, Mullarky E, Lu C, Bosch KN, Kavalier A, Rivera K, Roper J, Chio II, Giannopoulou EG, Rago C, Muley A, Asara JM, Paik J, Elemento O, Chen Z Pappin DJ, Dow LE, Papadopoulos N, Gross SS, Cantley LC. Vitamin C selectively kills KRAS and BRAF mutant colorectal cancer cells by targeting GAPDH. Science. 2015;350(6266):1391-6. doi: 10.1126/science.aaa5004, PMID 26541605.

45. Hwang NR, Yim SH, Kim YM, Jeong J, Song EJ, Lee Y, Lee JH, Choi S, Lee KJ. Oxidative modifications of glyceraldehyde-3-phosphate dehydrogenase play a key role in its multiple cellular functions. Biochem J. 2009;423(2):253-64. doi: 10.1042/BJ20090854, PMID 19650766.

46. Uetaki M, Tabata S, Nakasuka F, Soga T, Tomita M. Metabolomic alterations in human cells by vitamin C-induced oxidative stress [sci rep:2015]. Vol. 5. p. 1-9.

47. Park S, Ahn S, Shin Y, Yang Y, Yeom CH. Vitamin C in cancer: a metabolomics perspective. Front Physiol. 2018:9:762. doi: 10.3389/fphys.2018.00762, PMID 29971019.

48. Vissers MCM, Das AB. Potential mechanisms of action for vitamin $C$ in cancer: reviewing the evidence. Front Physiol. 2018;9:809. doi: 10.3389/ fphys.2018.00809, PMID 30018566.

49. Xu RH, Pelicano H, Zhou Y, Carew JS, Feng L, Bhalla KN, Keating MJ, Huang P. Inhibition of glycolysis in cancer cells: a novel strategy to overcome drug resistance associated with mitochondrial respiratory defect and hypoxia. Cancer Res. 2005;65(2):613-21. PMID 15695406.

50. Pelicano H, Martin DS, Xu RH, Huang P. Glycolysis inhibition for anticancer treatment. Oncogene. 2006;25(34):4633-46. doi: 10.1038/sj.onc.1209597، PMID 16892078.

51. Chen Q, Polireddy K, Chen P, Dong R. The unpaved journey of vitamin C in cancer treatment. Can J Physiol Pharmacol. 2015;93(12):1055-63. doi: 10.1139/ cjpp-2014-0509, PMID 26469874.

52. Mikirova NA, Ichim TE, Riordan NH. Anti-angiogenic effect of high doses of ascorbic acid. J Transl Med. 2008;6:50. doi: 10.1186/1479-5876-6-50, PMID 18789157.

53. Yeom CH, Lee G, Park JH, Yu J, Park S, Yi SY, Lee HR, Hong YS, Yang J, Lee S. High dose concentration administration of ascorbic acid inhibits tumor growth in BALB/c mice implanted with sarcoma 180 cancer cells via the restriction of angiogenesis. J Transl Med. 2009:7:70. doi: 10.1186/1479-5876-7-70, PMID 19671184.

54. Bhattacharya S, Ahmed KKM, Chakraborty S. Free Radicals Cardiovascular Diseases: An Update. Free Rad Antiox. 2011;1(1):17-22. doi: 10.5530/ax.2011.1.4.

55. Bhattacharya S. Medicinal plants and natural products in amelioration of arsenic toxicity: a short review. Pharm Biol. 2017:55(1):349-54. doi: 10.1080/13880209.2016.1235207, PMID 27931138.

56. Singh K, Bhori M, Kasu YA, Bhat G, Marar T. Antioxidants as precision weapons in war against cancer chemotherapy induced toxicity - exploring the armoury of obscurity. Saudi Pharm J. 2018;26(2):177-90. doi: 10.1016/j.jsps.2017.12.013, PMID 30166914.

57. van Gorkom GNY, Lookermans EL, Van Elssen CHMJ, Bos GMJ. The Effect of vitamin $\mathrm{C}$ (ascorbic acid) in the treatment of patients with cancer: a systematic review nutrients. 2019:11:977.

Cite this article: Bhattacharya S. Clinical Attestation and Redox Mechanism of Ascorbic Acid in the Treatment of Cancer. Free Radicals and Antioxidants. 2021;11(1):1-6. 